\title{
Değişken Odaklı Optik Görüntüleme Sistemi Tasarımı ve Üretimi
}

\author{
Mehmet POLAT ${ }^{1 *}$, Ebru GENÇ ${ }^{2}$ \\ ${ }^{1}$ Mekatronik Bölümü, Mühendislik Fakültesi, Fırat Üniversitesi, Elazığ, Türkiye \\ 2 TÜBİTAK SAGE, Ankara, Türkiye \\ ${ }^{* 1}$ mpolat@ firat.edu.tr, ${ }^{2}$ ebru.genc@ tubitak.gov.tr
}

\begin{abstract}
Öz: Optik, elektro-optik ve optomekanik bileşenler kullanılarak izlenmek istenen hedeflerin görüntülenmesi için oluşturulan sistemler optik görüntüleme sistemleri olarak adlandırılmaktadır. Farklı menzillerde bulunan hedefi net bir şekilde görüntülemek için değişken odaklı (zoom) optik görüntüleme sistemleri kullanılmaktadır. 'Zoom sistemleri' olarak da bilinen bu sistemlerin görüntü alabilmesi için objektifte bulunan mercek gruplarının bazılarının doğrusal olarak hareket etmesi gerekir. Bu hareket elle ya da motor yardımı ile sağlanabilir. Hareketli mercek grupları içerdikleri ve hassas konum kontrolü gerektirdiği için bu sistemlerin optik ve mekanik tasarımı zordur. Bu çalışmada değişken odaklı görüntüleme sistemleri hakkında genel bilgiler verilerek, sistemi oluşturan en uygun mekanizma tipine karar verilip sistemin tasarımı ve üretimi gerçekleştirilmiştir. Son olarak üretilen sistem tasarımsal olarak doğrulanmıştır
\end{abstract}

Anahtar kelimeler: Optik görüntüleme sistemi, Değişken odak sistemi, Zoom sistemi, Tasarım ve üretim.

\section{Design and Production of Variable Focus Optical Imaging System}

\begin{abstract}
Optical imaging systems are used to visualize the targets to be monitored using optical, electro-optic and optomechanical components. Variable-focus (zoom) optical imaging systems are used to clearly display the target at different ranges. These systems, also known as 'zoom systems', require some of the lens groups in the lens to move linearly in order to capture images. We can provide this motion by hand or by motor. The optical and mechanical design of these systems is difficult as they contain moving lens groups and require precise position control. In this article, by giving general information about variable focus imaging systems, the most appropriate mechanism forming the system is decided and the design and production of the system has been realized. The designed system has been verified produced system.
\end{abstract}

Key words: Optical imaging systems, Variable focus system, Zoom systems, Design and production.

\section{Giriş}

Optik, en genel ifade ile 1şık ve görme olaylarını inceleyen fizik koludur. Bu alanda 1şığa yön ve şekil vermek için yapılan tüm araç, gereç ve aygıtlar optik sistemler altında değerlendirilmektedir. Optik görüntüleme sistemleri temel olarak üç ana bölümden oluşmaktadır: objektif, dedektör ve görüntü işleme [1].

Objektif en temel anlamıyla mercekler, merceklerin konumlanmasını sağlayan optomekanik bileşenler ve bahsedilen elemanları içeren mekanik bütünden oluşan kısımdır. Görüntülenmek istenen hedeften gelen 1şınlar objektiften geçerek, dedektöre iletilir. Çalışma prensibine göre objektifler ikiye ayrılmaktadır: Odak uzaklığ değişen (zoom objektif) ve odak uzaklığı değişmeyen (prime lens) objektifler. Objektife dışarıdan gelen 1şık belirli bir noktada toplanır. Bu noktayla algılayıcı veya film arasında olan uzaklığa odak uzaklığı (focal length) adı verilir. Görüş açısı (field of view, FOV), açısal veya gözlenebilir doğrusal alan olarak tanımlanabilir. Burada önemli olan husus; odak uzaklığının objektifin görüş açısıyla ters orantılı olmasıdır. Odak uzaklığı azaldıkça görüş açısı artar, odak uzaklığı arttıkça ise görüş açısı azalır. Bundan dolayı objektifler normal, geniş ve dar açılı objektifler olarak adlandırılir.

Dedektör; gelen 1şınları elektrik sinyaline çevirerek görüntünün işlenmesine olanak sağlar. Görüntü işleme, görüntüyü dijital form haline getirmek ve bazı işlemleri gerçekleştirmek için geliştirilmiş, spesifik görüntü elde etmek ya da ondan bazı yararlı bilgiler çıkarmak için kullanılan bir yöntemdir. Bu yöntemin girdisi video kesiti veya fotoğraf gibi bir görüntüdür. Çıktısı ise görüntünün istenilen ya da dikkat edilmesi gereken bölümüne karşılık gelir. Genellikle görüntü işleme sistemi, önceden belirlenmiş sinyal işleme (Signal Processing) yöntemlerini uygularken görüntüleri iki boyutlu sinyaller olarak ele alır.

\footnotetext{
${ }^{*}$ Sorumlu yazar: mpolat@ firat.edu.tr. Yazarların ORCID Numarası: ${ }^{1}$ 6188-8726, ${ }^{2}$ 2959-2041
} 
Optomekanik tasarım; optik tasarım ile elde edilen merceklerin ve mercek gruplarının yerleştirildiği mekanik parçaların tasarlandığı kısımdır [2]. 'Zoom sistemleri' olarak da bilinen değişken odaklı sistemler odak uzaklığını değiştirerek farklı görüş açılarında görüntü almayı sağlamaktadır. Bu görüntüyü alabilmesi için zoom sistemlerinde bulunan mercek gruplarının bazılarının doğrusal olarak hareket etmesi gerekir. Bu hareket elle ya da motor yardımı ile sağlanabilir. Hareketli mercek grupları içerdikleri ve hassas konum kontrolü gerektirdiği için bu sistemlerin optik ve mekanik tasarımı zordur.

Değişken ve sürekli odaklı sistemlerde (continuous zoom systems) sabit bir odak uzunluğu yoktur. Bu iki sistemin birbirinden farkı ise şöyle açıklanabilir: Eğer bir sistemin toplam odak uzunluğu boyunca her odak noktası için net görüntü elde edilebiliyorsa bu sistem sürekli odaklı sistemdir, ancak odak uzunluğunun her noktasında değil de belirli noktalarında net görüntü elde edilebiliyorsa bu sistem değiş̧en odaklı bir sistemdir. Değişken odaklı ve sürekli odaklı görüntüleme sistemlerinde iki farklı hareket grubu bulunmaktadır; bunlar zoom ve odak kısımlarıdır. Zoom kısmındaki hareketler görüş açısını ayarlarken, odak kısmındaki hareketler görüntünün kalitesini yani netliğini ayarlar. Bu kısımlar için iki ayrı mekanizma tasarımı gereklidir.

Değiş̧ken odaklı sistemlerde optik tasarım kısmı zor olduğu için bu alanda yapılan yayınların büyük çoğunluğu optik tasarım ile ilgilenmiş olup mekanik tasarım ve kontrole çok az ya da hiç değinmemişlerdir. Li Y. ve ekibinin yaptığı çalıșmada $10 \mathrm{X}$ zoom oranına sahip bir sistemin mekanik ve optik tasarımı yapılmış, Sekil 1'de üç boyutlu çizimi ve tamamlanmış hali gösterilen bu sistemde zoom kısmında hareketli tek bir mercek grubu bulunurken odak kısmında da hareketli tek bir mercek grubu bulunmaktadır. Hareketli mercek grupları adım motorlar kullanılarak çalı̧̧ıııılmış ve konum bilgisini doğrusal olarak elde etmek için yatay dirençli algılayıcı kullanılmıștır [3].
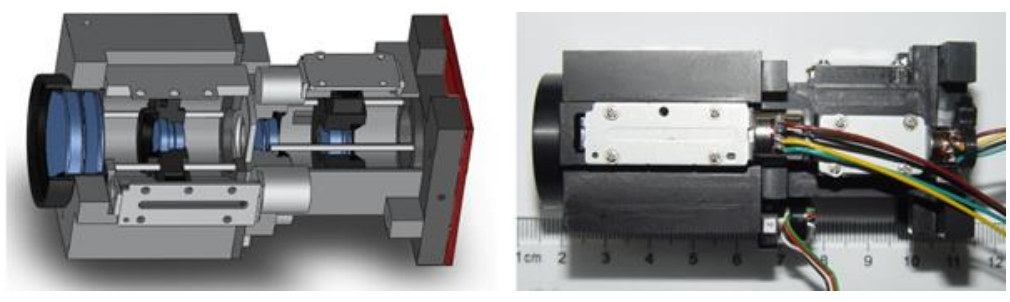

Şekil 1. 10X zoom oranına sahip bir sistemin mekanik tasarımı [3]

Sanson M. C ve ekibinin yapmış olduğu çalışmalarda ise orta dalga boylu kızılötesi sistemler için sürekli odaklı bir sistem tasarlanmıştır. İki ayrı bölümden oluşan bu çalışmanın birinci kısmında optik tasarım ve analizi yapılırken, ikinci kısımda mekanik tasarıma da değinilmiş̧tir. Mekanik tasarım sadece katı model olarak yayında yer almaktadır $[4,5]$

Yan-qin S. ve ekibinin yaptığı çalışmada sürekli odaklı kızılötesi görüntüleme sistemleri için mekanizma tasarımı incelenmiştir [6]. Bu çalışmada ve daha bir çok yerde zoom sistemleri için kam mekanizmasının kaçınılmaz olduğu belirtilmiş̧ir. Zoom mekanizması için silindirik kam tercih edilirken; odak mekanizması için vida mekanizması (screw nut) tercih edilmiștir. Çalışmada zoom ve odak mekanizmalarının tasarımı ve sonlu elemanlar yöntemi ile analizi incelenmiștir. [7] nolu çalışmada ise kam profil tasarımın zoom sistemleri için kaçınılmaz olduğu belirtilerek, ZEMAX tabanlı zoom sistemleri için optimum kam profili tasarımı incelenmiştir. Burada ZEMAX programlama dili (ZEMAX Programing Language, ZPL) kullanılmıştır. Zoom mercekleriyle ilgili yapılan bir çalışmada, bu merceklerin yapısal ve işlevsel olarak son yıllardaki gelişimi incelenmiştir [8].

Sürekli odaklı sistemlere kesintisiz büyütme sistemi de denilmektedir [9]. Bu makale sürecinde endüstride de bu sistemleri üreten önde gelen firmaların katalogları incelenerek sistemlerin genel yapısı, mekanizması, fiziksel özellikleri (boyut, ağırlık vb.) hakkında bilgi sahibi olunmuştur. Şekil 2'de endüstride bulunan sürekli odaklı görüntüleme sistemi örneği sunulmuştur [10]. Yapılan benzer sistemin incelemeleri sonucunda, bu tip sistemlerde iki farklı hareket yönteminin kullanıldığı görülmüştür: motorlu sürekli zoom (motorized continuos zoom) sistemleri ve manuel sürekli zoom sistemleridir. 

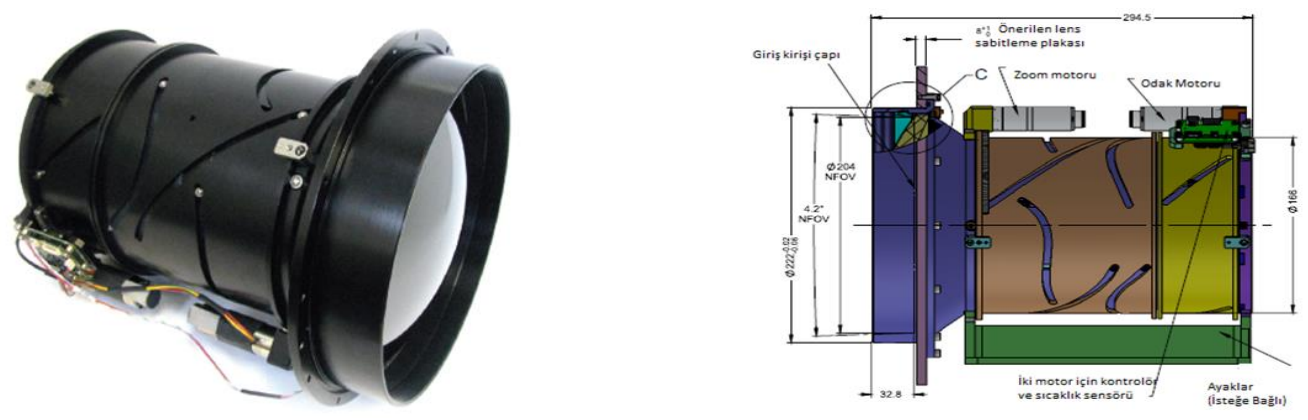

Şekil 2. Endüstride bulunan sürekli odaklı görüntüleme sistemi [10]

Yapılan araştırmalar sonucunda; bu sistemlerde genelde iki motor kullanıldığı görülmüştür. Ayrıca zoom sistemlerinin mekanizmasında çoğunlukla kam mekanizmasının tercih edildiği gözlemlenmiştir.

\section{Sistem Tasarımı}

\subsection{Sistemin Gereksinimlerinin Belirlenmesi}

Optik görüntüleme sistemleri için değiş̧en odaklı sistem tasarımı kapsamında hazırlanacak deney düzeneğinden beklenen; yapılan optik tasarıma boyutsal ve işlevsel olarak uygun mekanizmanın tasarlanmasıdır.

\subsection{Optik Tasarım}

Sistem tasarımın yapılabilmesi için öncelikle optik tasarımın yapılması gerekir. Değişken odaklı görüntüleme sisteminin tanımında belirtildiği gibi odak uzunluğunun belirli noktalarında görüntü almak için mercek ve mercek gruplarının optik yol üzerindeki konumları optik tasarım sonucunda belirlenmiştir.

Bu çalışma kapsamında Şekil 3' te belirtilen optik tasarım kullanılmıştır. Tasarımda odak uzunluğu aralığ 15 ila 300 mm'dir. Bu tasarım için 3 ve 4 numaralı merceklerinden oluşan mercek grubu zoom mercek grubunu temsil etmektedir. Tablo 1'de görüldüğü üzere 3 ve 4 numaralı mercekler arasındaki mesafe (s1) sabit olup bu iki mercek bir bütün olarak doğrusal hareket edecektir. 5 ve 6 numaralı merceklerden oluşan mercek grubu ise odak mercek grubunu temsil etmektedir, burada da 5 ve 6 numaralı mercekler arasındaki mesafe (s2) sabit olup bu iki mercek bir bütün olarak doğrusal hareket edecektir.

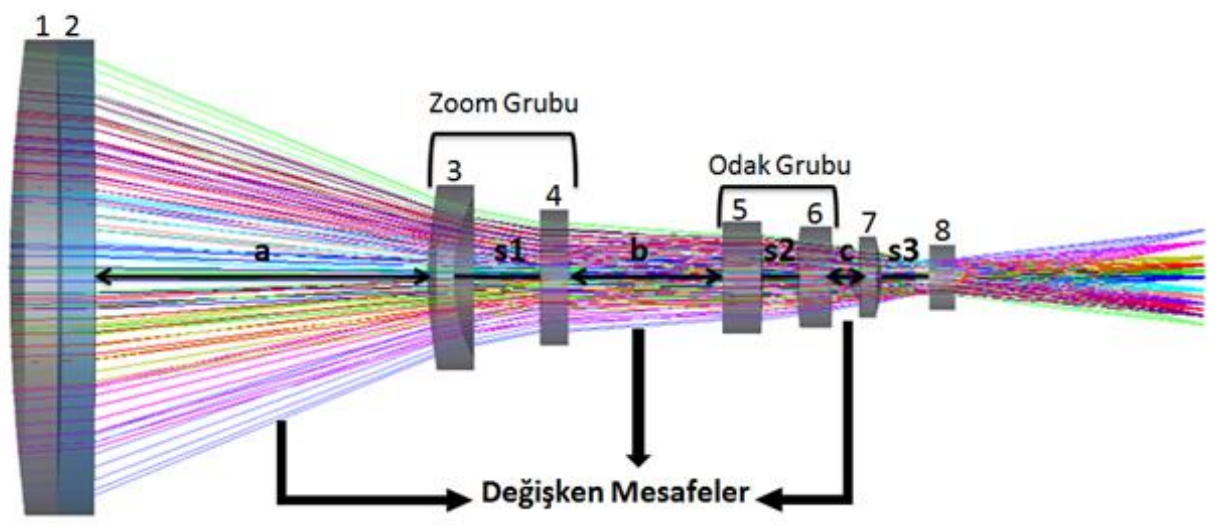

Şekil 3. Optik tasarım 
Tablo 1. Konfigürasyon tablosu

\begin{tabular}{|l|l|l|l|l|l|}
\hline $\begin{array}{l}\text { Mesafeler } \\
(\mathbf{m m})\end{array}$ & $\begin{array}{l}\mathbf{1 5} \mathbf{~ m m} \\
\text { Odak }\end{array}$ & $\mathbf{1 0 0}$ mm Odak & $\mathbf{1 5 0}$ mm Odak & $\mathbf{2 0 0}$ mm Odak & $\begin{array}{l}\text { 300 mm } \\
\text { Odak }\end{array}$ \\
\hline $\mathbf{a}$ & 9,908 & 50,248 & 54,944 & 54,604 & 55,841 \\
\hline $\mathbf{s 1}$ & 15,379 & 15,379 & 15,379 & 15,379 & 15,379 \\
\hline $\mathbf{b}$ & 61,878 & 24,453 & 17,043 & 12,008 & 5,94 \\
\hline $\mathbf{s 2}$ & 10 & 10 & 10 & 10 & 10 \\
\hline $\mathbf{c}$ & 5 & 4,999 & 6,017 & 12,169 & 15,004 \\
\hline $\mathbf{s 3}$ & 5,142 & 5,142 & 5,142 & 5,142 & 5,142 \\
\hline
\end{tabular}

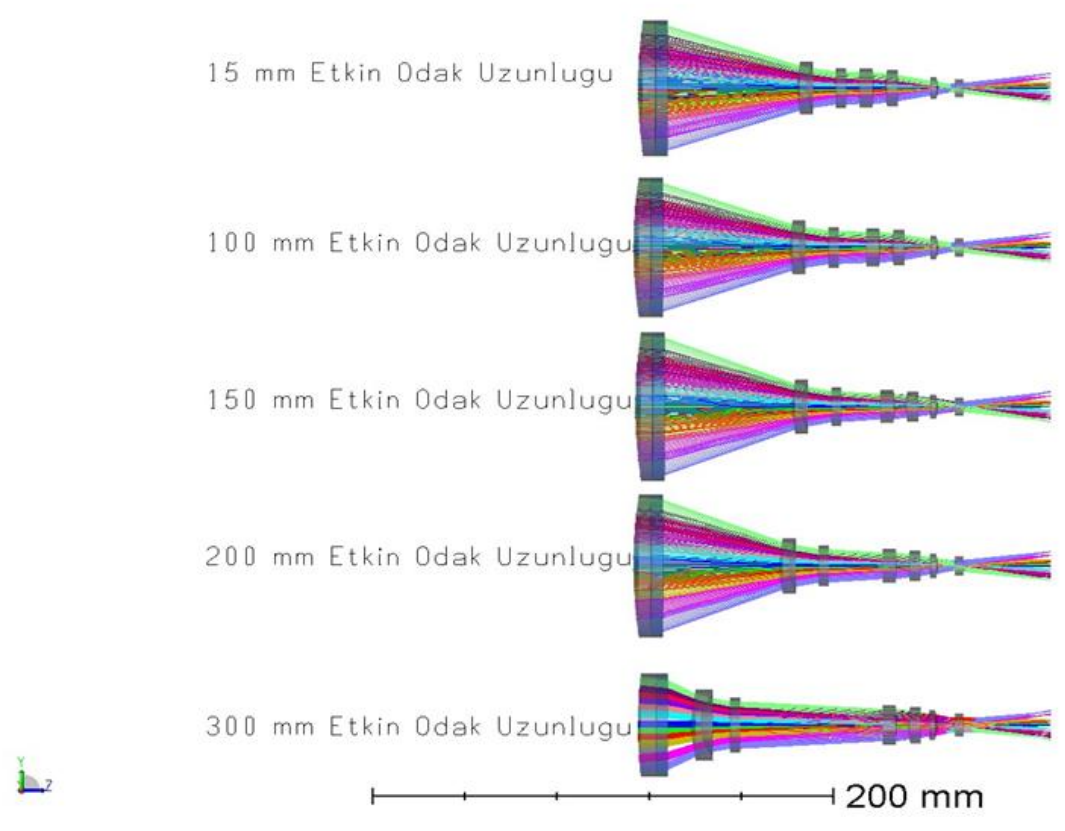

Şekil 4. Konfigürasyon hareketlerinin gösterimi

Aslan S. yapmış olduğu sürekli odaklı optik tasarım çalışmasında; hareket eden merceklerin hareketinin devamlı ve her konumda sistemin odaklı bir görüntü sağlayabilmesi amacıyla dar görüş açısından genişe kadar toplam 32 konfigürasyon olușturulmuştur. Toplamda 32 konfigürasyon kullanılmasının en önemli nedeni sürekli görüş açısı değiştiren ve devamlı odaklı olması gereken bu tip sistemlerde hareketli merceklerin hareketinin de devamlı olması ve üretilebilir bir eğrinin bu merceklerin pozisyonlarına uydurulması gereklidir. Optimum konfigürasyon sayısı, her konumda odaklı bir tasarıma ulaşılabilmesi ve tasarım süresinin kabul edilebilir seviyede kalabilmesi açısından en önemli parametredir. Bu tip bir optik tasarım oldukça karmaşı optimizasyon ve performans analiz adımlarını içerir [11].

\subsection{Optomekanik Tasarım}

Şekil 4'de gösterilen optik tasarım katı model programına aktarılarak merceklerin çap ve kalınlık ölçüleri belirlenerek Tablo 2'de sunulmuştur. 
Tablo 2. Mercek çap ve kalınlıkları

\begin{tabular}{|l|l|l|}
\hline Mercek Numarası & Kalınlık (mm) & Çap (mm) \\
\hline $1-2$ & 10.98 & 80 \\
\hline 3 & 2.75 & 55 \\
\hline 4 & 2.39 & 50 \\
\hline 5 & 5.04 & 60 \\
\hline 6 & 4.35 & 55 \\
\hline 7 & 5.75 & 40 \\
\hline 8 & 4 & 35 \\
\hline
\end{tabular}

Mercekleri sistemin mekanik modeline eklemek için gerekli olan optomekanik parçaların Şekil 5-8'de gösterildiği gibi tasarımı yapılarak, işlevine uygun olarak dört mercek grubu şeklinde modellenmiştir.

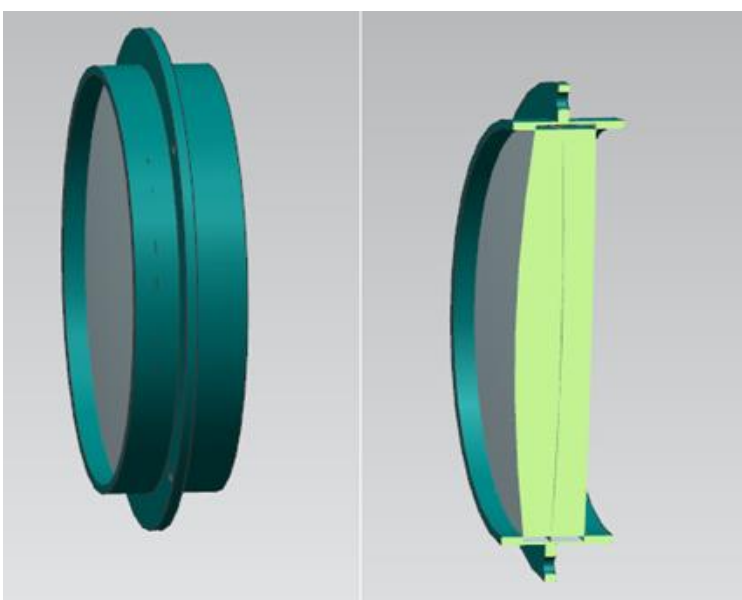

Şekil 5. Birinci mercek grubunun optomekanik tasarımı

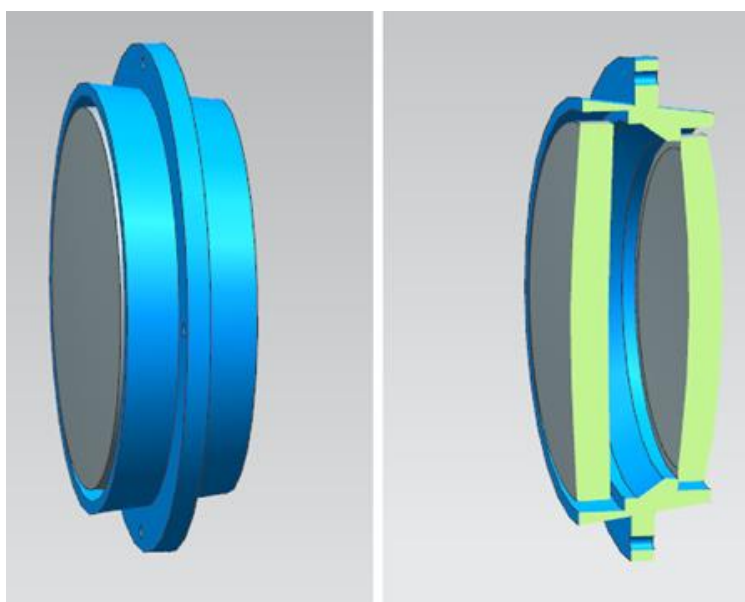

Şekil 7. Üçüncü mercek grubunun optomekanik tasarımı

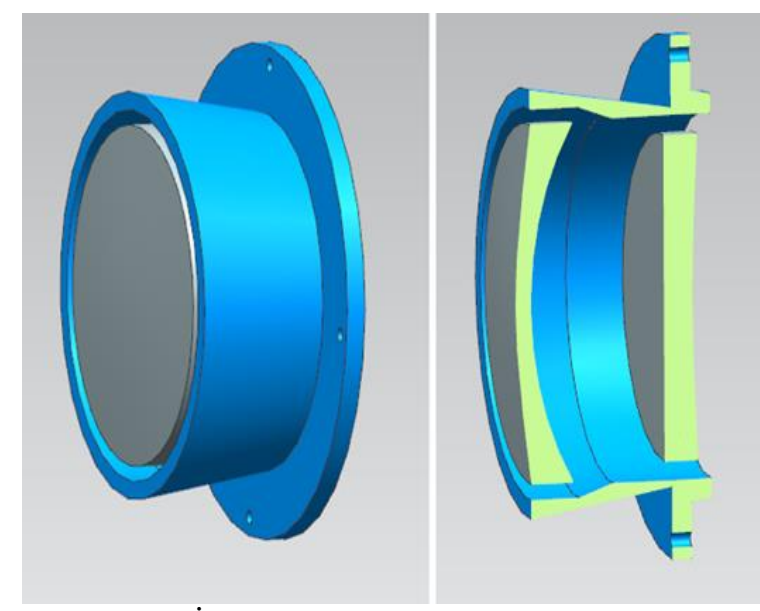

Şekil 6. İkinci mercek grubunun optomekanik tasarımı

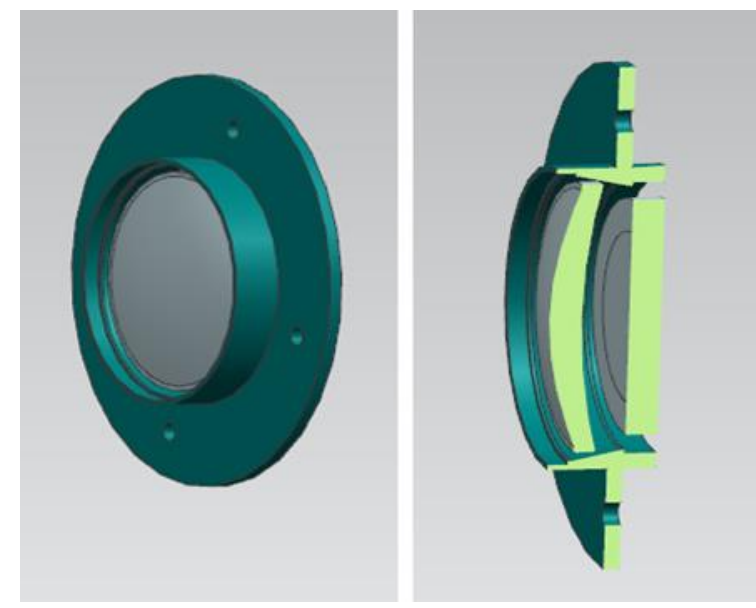

Şekil 8. Dördüncü mercek grubunun optomekanik tasarımı 


\subsection{Hareket Mekanizması Sentezi}

Değişken odaklı ve sürekli odaklı görüntüleme sistemlerinde iki farklı hareket grubu bulunmaktadır; bunlar zoom ve odak kısımlarıdır. Zoom kısmındaki hareketler görüş açısını ayarlarken, odak kısmındaki hareketler görüntünün kalitesini yani netliğini ayarlar. Bu kısımlar için iki ayrı mekanizma tasarımı gereklidir. Zoom ve odak sistemlerinde oluşturması gereken hareket doğrusal harekettir. Mercek grupları doğrusal olarak hareket etmektedir. Döner motordan hareketi alıp doğrusal harekete çevirerek mercek gruplara aktaracak mekanizmalar kullanılacaktır. Yapılan literatür çalışmasında zoom ve odak mekanizmaları birbirinden bağımsız hareket ettirildiği için bağımsız mekanizmaların kullanıldığı gözlemlenmiştir.

Zoom ve odak mekanizmaları için literatür de farklı çalışmalar yer almaktadır. Literatür de zoom ve odak mekanizmalarının her ikisi için de kam mekanizması kullanmış çalışmalar olmakla birlikte yine her iki mekanizma için vida sistemlerinin (lead screw ve ball screw) kullanıldığ çalışmalarda bulunmaktadır. Ayrıca zoom mekanizması için kam mekanizmasının tercih edildiği ve odak mekanizması için vida mekanizmasının kullanıldığı çalışmalar da bulunmaktadır. Genel olarak optik tasarım sonuçlarına göre zoom mekanizmasının hareket aralığı odak mekanizmasının hareket aralığından daha büyüktür. Bu nedenle odak kısmındaki hareketler daha hassas hareketler içerir.

\subsubsection{Zoom Mekanizması}

Literatürde zoom sistemleri için kam mekanizmasının kaçınılmaz olduğu belirtilmiştir. Bununla birlikte zoom sistemlerini endüstriyel anlamda üreten firmaların katalogları da incelenerek kam mekanizmasının kullanıldığı görülmüştür. Ayrıca kam mekanizmaları zoom sistemlerine geniş hareket imkânı sağladığı gözlemlenmiştir. Örneğin zoom sisteminde hareketli mercek grubu sayısının birden fazla olduğu bir optik tasarımda her bir mercek grubu için kam profili belirlendikten sonra tek motor kullanarak birden çok mercek grubu hareket ettirilebilir ve kam profilinin şekline göre bu mercek grupları aynı veya zıt yönde hareket ettirilebilir. Ayrıca yine kam profiline bağlı olarak bir konfigürasyonda sadece bir mercek grubu hareket ettirilip diğer mercek grupları konumlarını koruyabilir.

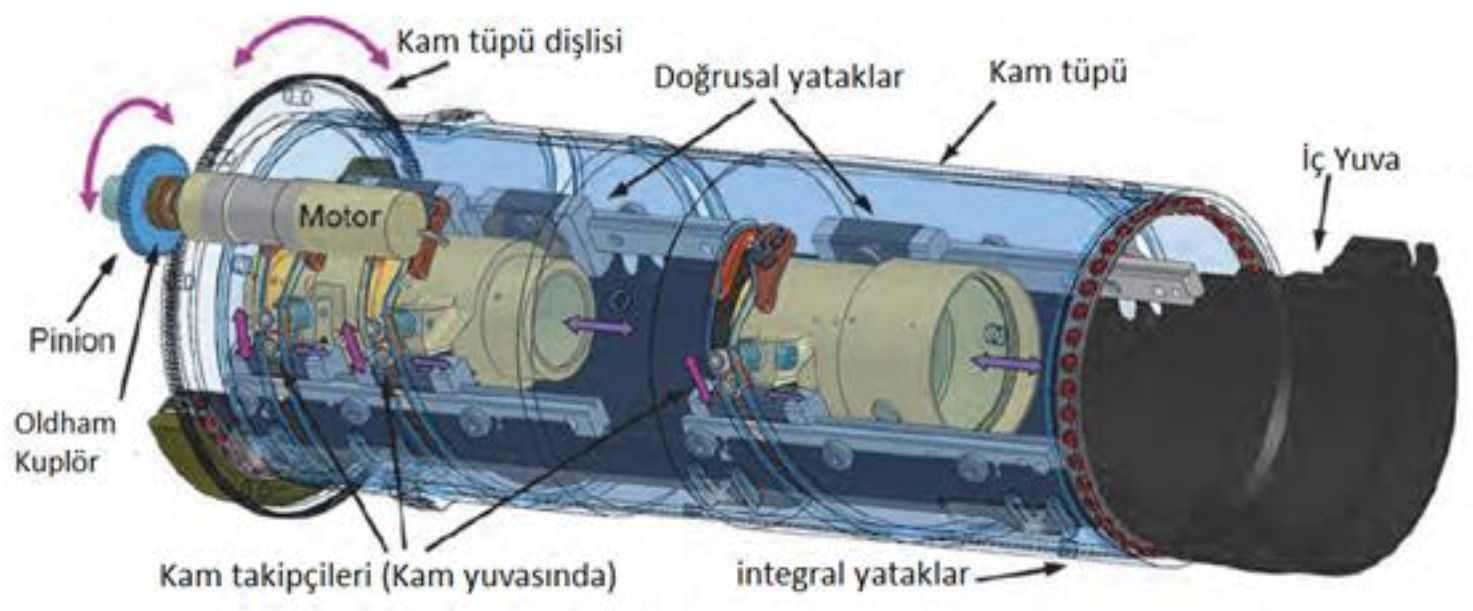

Şekil 9. Zoom mekanizması [12]

Şekil 9'daki tasarımın yer aldığı çalışmada zoom mekanizması hareketli üç mercek grubundan oluşmaktadır. Yapılan çalışmada zoom mekanizması olarak kam tercih edilmiştir [12]. Kam makine dinamiğinde sırası ile kendisine temas eden düzenekleri harekete geçirmeye yarayan bir mekanizmadır. Şekil 10'da kam mekanizmasının genel yapısı sunulmuştur [13]. Kam mekanizmalarının genel olarak kamın şekline göre, izleyicinin şekli ve hareketine göre, kam ve izleyicinin temas şekline göre sinıflandırılabilir. 


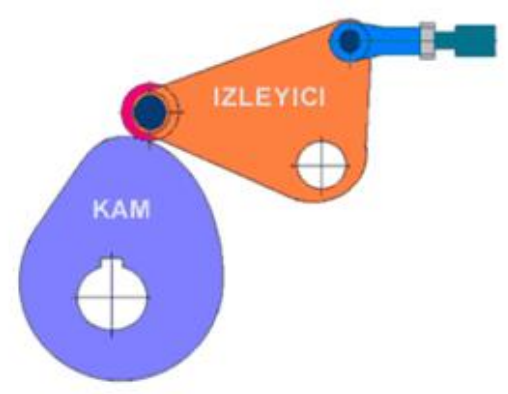

Şekil 10. Kam mekanizmalarının genel yapısı [13]

Kam mekanizmaları dönme hareketini öteleme ya da salınım hareketine dönüştüren sistemlerdir. $\mathrm{Bu}$ mekanizmalar vasıtasıyla açma - kapama, bekleme ve bunların çeşitli sırayla dizilimi gibi karmaşık hareketler gerçekleştirilebilir. Senkronize hareket gereken yerlerde kullanımı oldukça iyidir. Mesela araç sübap kapaklarının belli bir sürede açılıp kapanması ya da beklemesi gibi çok hızlı ve senkronize olması gereken hareketleri oldukça iyi gerçekleştirebilirler. Zoom sistemlerinde kullanılan kam mekanizması silindirik kam mekanizmasıdır.

Silindirik kam mekanizması ile oluşan sistemlerde, doğrusal hareket yapan izleyicinin konumuna göre mekanizma farklılık gösterir. Doğrusal hareket yapan izleyicinin, silindirik kamın dışarısında yataklandığı mekanizmaya örnek Şekil 11'de verilmiştir [14].

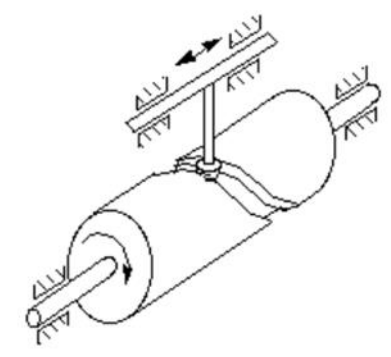

Şekil 11. İzleyicinin konumuna göre silindirik kam [14]

Zoom sisteminde izleyici kısmı hareketli mercek gruplarından oluşacak olup, silindirik kamın içerisinde yer alır ve silindirik kam üzerinde bulunan profile mekanik bir parça yardımıyla ilişkilendirilir. Sonrasında silindirik kam motor yardımıyla dönerken içerisinde bulunan mercek grupları kam profiline göre doğrusal olarak hareket eder. Silindirik kamda bulunan profil sayısı hareketli mercek grubu sayısı tarafindan belirlenir. Silindirik kamda bulunan profilin şekli ise merceklerin hareket aralığı yani yatay olarak yapacağı yer değiştirme ve tanımlanan matematiksel fonksiyon ile sağlanır. Bu fonksiyona kam hareket eğrisi denir, hareket eğrisi; kamın dönme açısına karşl1ık gelecek izleyicinin konumunu belirler. Örnek hareket eğrisi Şekil 12'de verilmiştir, burada kam hareket diyagramında $\mathrm{s}=\mathrm{f}(\theta)^{\prime}$ dir.

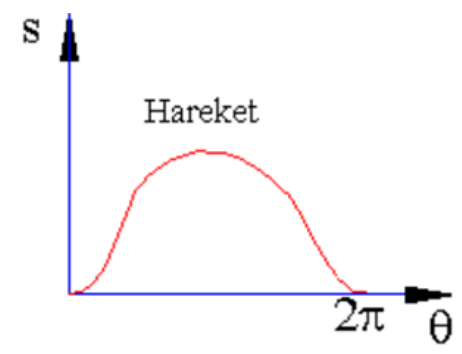

Şekil 12. Hareket eğrisi örneği [14] 
Hareket eğrisi profili (s), kam kinematiği açısından önemlidir, kısaca açıklanacak olursa hareket eğrisi kamın yer değiştirmesini verir, bu eğrinin türevleri ise sırasıyla hız (v), ivme (a) ve sarsı (j) dediğimiz değerleri verir, bu grafiklerin hepsini kapsayan diyagrama "svaj diyagramı" denir.

$\mathrm{Bu}$ nedenle hareket eğrisi tanımlayarak, kinematik olarak hız ve ivme gibi büyüklüklere karar verilmiş olunur. $\mathrm{Bu}$ tasarım tersten de yapılabilir yani istenilen işleve hıza ve ivmeye bağlı tasarım yapılabilir, ancak tasarım yapılırken mümkün olduğunca sürekli fonksiyonlar tercih edilmelidir, Şekil 13'de gösterildiği gibi sürekli olmayan bir fonksiyon seçildiğinde, eğrinin türevlerinde sonlu olmayan değerlerle karşılaşılır, bu istenmeyen bir durumdur [15].

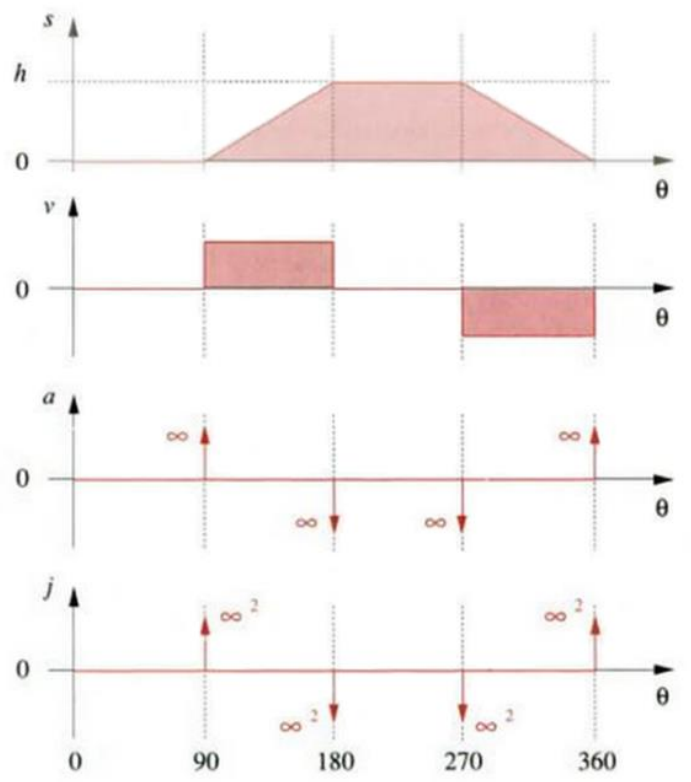

Şekil 13. Svaj diyagramı örneği [15]

Doğrusal hareket eğrisinde başlangıç ve bitiş noktaları sonsuz ivme olduğundan dolayı uygulamada sorun yaratacaktır. Başlangıç ve bitiş noktalarında sonsuz ivmeyi önlemek için, başlangıç ve bitiş bir daire yayı, arada ise bu iki daire yayına teğet bir doğru çizilerek elde edilen yükseliş eğrisinde hareket ve hareketin birinci türevi sürekli olacak, ivme ise her noktada sonlu bir değer alacaktır. Şekil 14'de gösterildiği gibi genel olarak daire yayı yarıçapı yükselme mesafesine $(\mathrm{H})$ eşit alınır ise de, farklı bir çap da kullanılabilir [16].

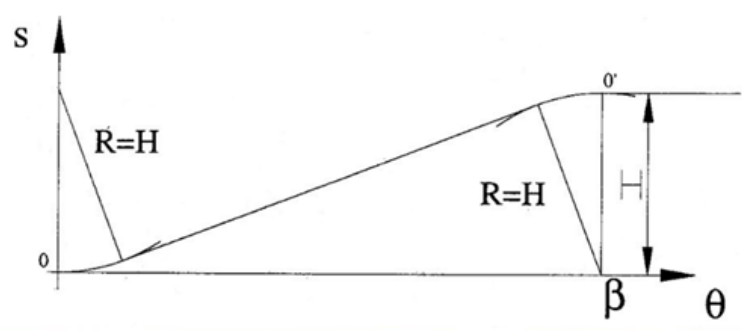

Şekil 14. Doğru ve daire yayı-birleşik eğriler [16]

$\mathrm{Bu}$ makalede tasarlanan silindirik kam Şekil 15'de gösterilmektedir. Optik tasarımdaki zoom mercek grubunun hareket aralığına göre tasarlanmıştır. Kamın boyutsal tasarımı ise öncelikle mercek çapları, merceklerin yerleştirildiği optomekanik çapları göz önüne alınarak belirlenmiştir. Tasarım yapılırken kam ile birlikte 
kullanılacak olan rulman ve dişlilerin mekanizmadaki yerlerine dikkat edilmiştir, rulmanlar için dayama yüzeyi oluşturulmuş, dişliler içinse bağlantı sağlayacak cıvata delikleri uygun şekilde konumlandırılmıştır.

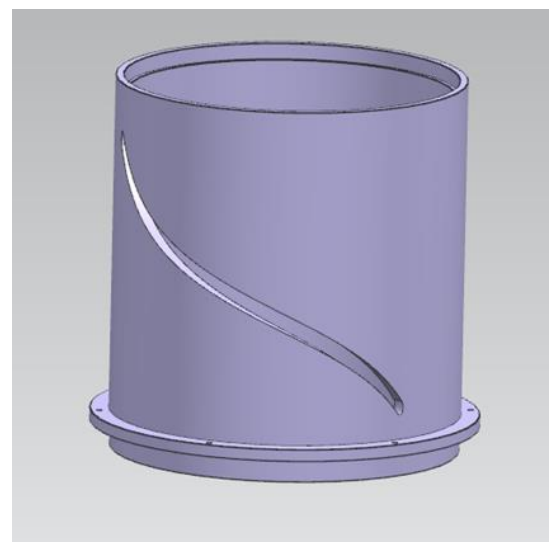

Şekil 15. Tasarlanan silindirik kam

\subsubsection{Odak Mekanizması}

Bilindiği gibi odak mekanizması için de çeşitli mekanizma seçenekleri bulunmaktadır. Zoom mekanizmasındaki gibi silindirik kam mekanizması ile oluşturulan odak mekanizmaları olduğu gibi vida sistemlerinden oluşan odak mekanizmaları da vardır. Ancak odak mekanizması için genelde vida sistemleri, bilye vidaların; hafif olmaları, hızlı olmaları ve esnek hareket aralığı sunmaları gibi nedenlerden dolayı tercih edilmektedir. Şekil 16 ve Şekil 17 'de odak mekanizması için vida sistemlerinin kullanıldığı örnek tasarımlar sunulmuştur.

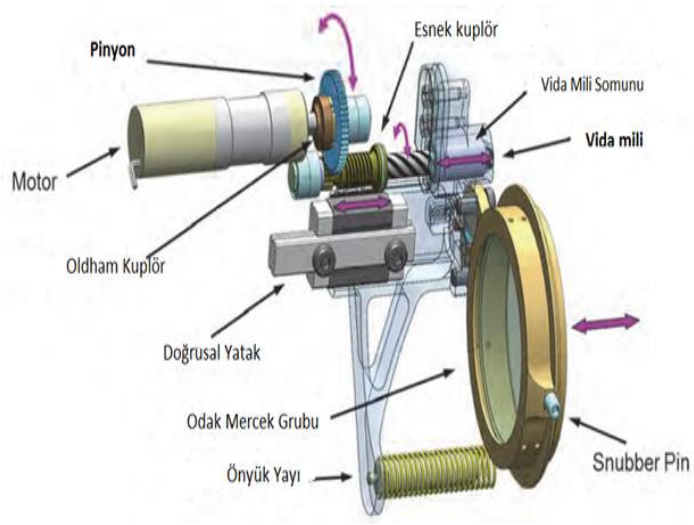

Şekil 16. Odak mekanizması [15]

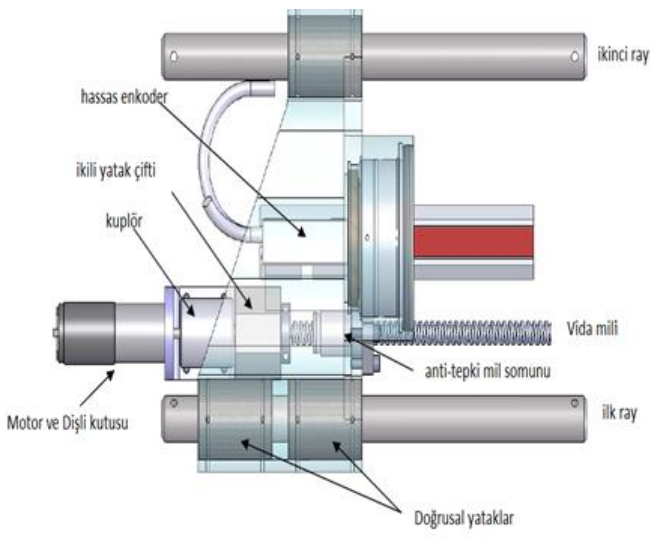

Şekil 17. Odak mekanizması tasarım örneği [5]

Vida mekanizmaları hareketi iletme ve değiştirme amacı ile kullanılır. Cıvata- somun sistemi denilen bu sistemler hareket bakımından şu şekilde sınıflandırılır [17]:

1. Somun sabit, cıvata dönme ve öteleme hareketi yapar; örneğin vinçlerde ve preslerde olduğu gibi.

2. Civata sabit, somun dönme ve öteleme hareketi yapar.

3. Civata dönme hareketi, somun öteleme hareketi yapar.

4. Somun dönme hareketi, crvata öteleme hareketi yapar.

Vidalı mil, bilye yataklı bir somunun vida dişleri açılmış bir mil üzerindeki sistem sayesinde dönme hareketini doğrusal harekete çeviren makine elemanıdır. Bu hareket esnasında sürtünmenin azaltılabilmesi amacıyla somun ile mil arasında yer alan boşlukta yataklanan bilyeler mevcuttur. Hareket aktarımı için kullanılan vidalı miller, 
doğrusal hareketi bu sayede daha az sürtünme ile iletirler. Hassas bir vida olarak yapılan dişli mil ise helis yapıdaki kanalları sayesinde bilye yataklarının rahat hareketine olanak sağlar. Bu hareket aktarma elemanı, düşük sürtünme özelliği sayesinde yüksek mekanik verime sahiptir. Vidalı milin temel yapısı Şekil 18'de sunulmaktadır [18].
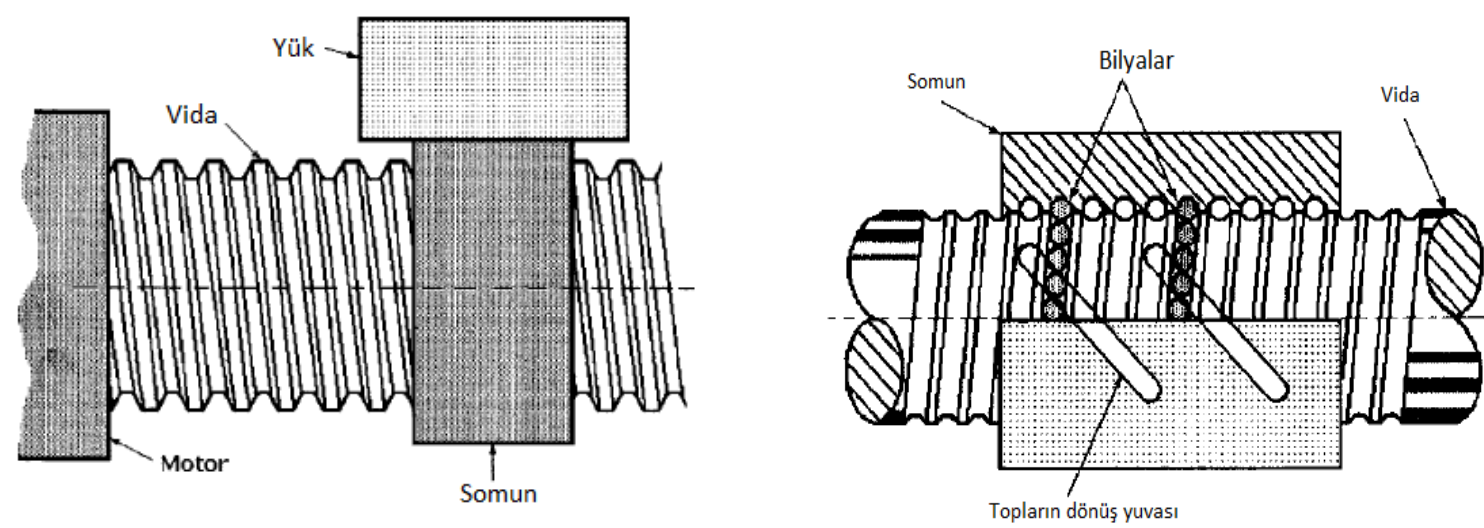

Şekil 18. Vidalı mil [18]

Çeşitli özellikleri sayılabilecek vidalı miller yüksek hassasiyete sahip, uzun ömürlü kullanımları olan ve düşük kirlilik üreten makine elemanlarıdır. Spesifik özellikleri nedeni ile hassas konumlama ve makine sanayiindeki hassas ölçüm sistemlerinde önemli bir yere sahip olan vidalı miller, robotlarda, çok hassas ekipmanlarda ve daha birçok endüstriyel uygulamalarda kullanılmaktadır.

\subsection{Sistem Bütünü Tasarımı}

Mercek grupları modellendikten sonra sistemin mekanik tasarımında kullanılacak olan mekanizma tiplerine uygun tasarımlar yapılmıştır. Yapılan tasarım sonucunda, tasarlanan parçalar üretilmiş ve seçilen hazır parçalar tedarik edilmiştir.

Tasarım parçaları;

1. Silindirik kam; Şekil 15 'de sunulmuştur.

2. Mercek gruplarının ve doğrusal yataklama elemanlarının yer aldığı sabit kısım; bu tasarım için sabit kısım silindirik kam içerisinde yer almaktadır. Parçanın tasarımı Şekil 19'da gösterilmiştir. Parça üzerinde rulmanların oturacağı dayama yüzeyleri, doğrusal yatakların oturması için gerekli olan cıvata delikleri, silindirik kam izleyicisinin doğrusal hareketi için gerekli olan oyuk ve odak mekanizmasının doğrusal hareketi için tasarlanan oyuk yer almaktadır.

3. Sabit kısım içerisinde yer alan, doğrusal yatak Şekil 20’de gösterilmiştir. Hareketli mercek grubu sayısına göre doğrusal yatakta olması gereken araba sayısı belirlenmiştir. Optik yol uzunluğuna bağlı olarak doğrusal yatağın boyu belirlenmiştir

4. Şekil 15 de gösterilen silindirik kam ile Şekil 19'da gösterilen sabit kısım arasına, Şekil 21 'de gösterilen ince kesit rulmanlar seçilmiştir.

5. Sistemin yerleşeceği alt tabla ve tutucular Şekil 22'de gösterildiği gibi tasarlanmıştır.

7. Kam mekanizmasına dönel hareket aktarımı için dişli tasarımı yapılmıştır, dişli tasarımının ve motorun konumlandırılması Şekil 23'de gösterilmiştir.

8. Odak mercek grubunun hareketi için seçilen motorun konumlandırılması ve bağlantı ara yüzleri Şekil 24'te gösterilmiştir. Odak mercek grubunun hareket ölçümü için doğrusal potansiyometre kullanılmıştır. 


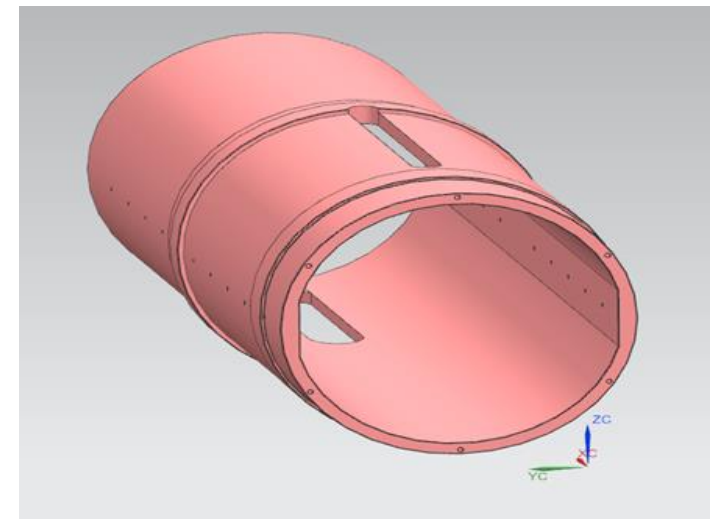

Şekil 19. Sabit kısım

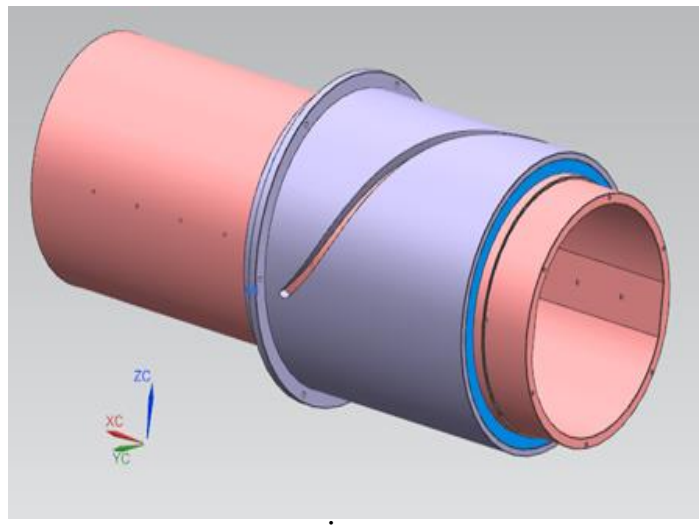

Şekil 21. İnce kesit rulman

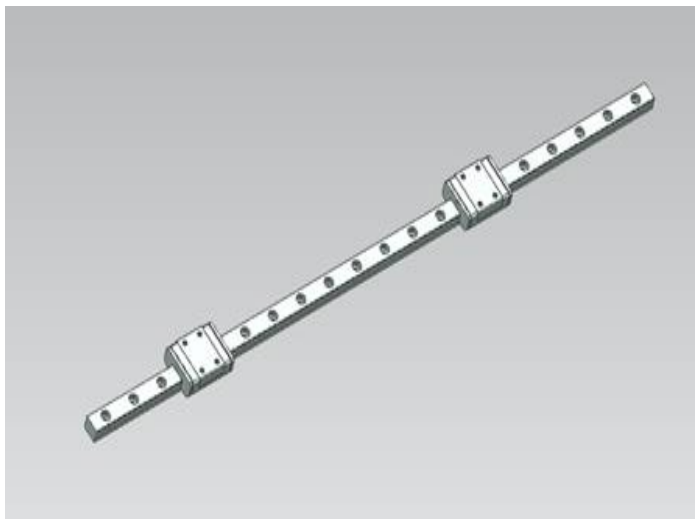

Şekil 20. Doğrusal yatak

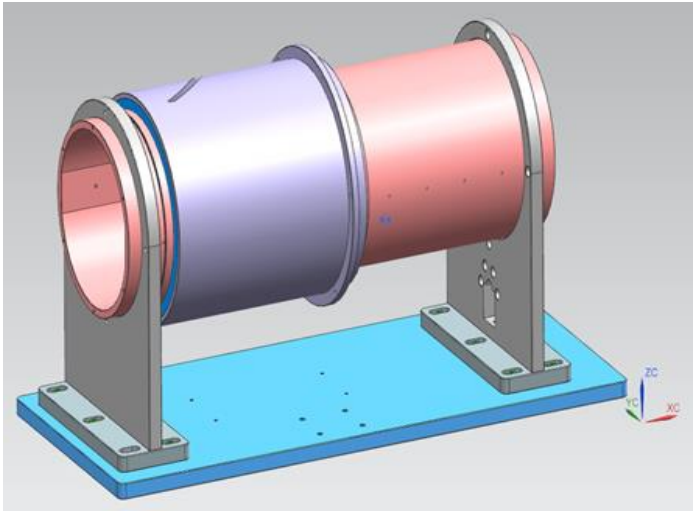

Şekil 22. Alt tabla ve tutucu ayakların tasarımı

9. Silindirik kam mekanizması ile hareket ettirilecek olan zoom mercek grubunun konumlandırılması Şekil 25 'de gösterilmiştir. Hareket için gerekli olan bağlantı ara parçaları tasarlanmıştır.

10. Hareketsiz mercek grupları için ön ve arka kapak tasarlanarak Şekil 26 'da gösterilmiştir, bağlantı ara yüzleri oluşturulmuştur.

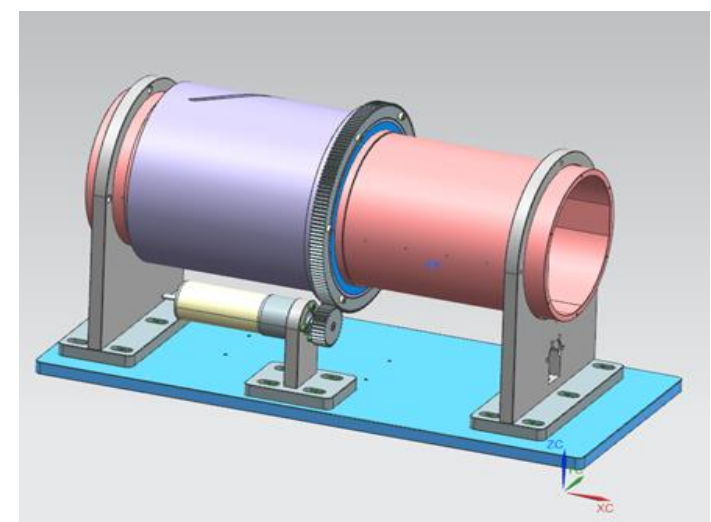

Şekil 23. Dişli tasarımının ve zoom motorunun konumlandırılması

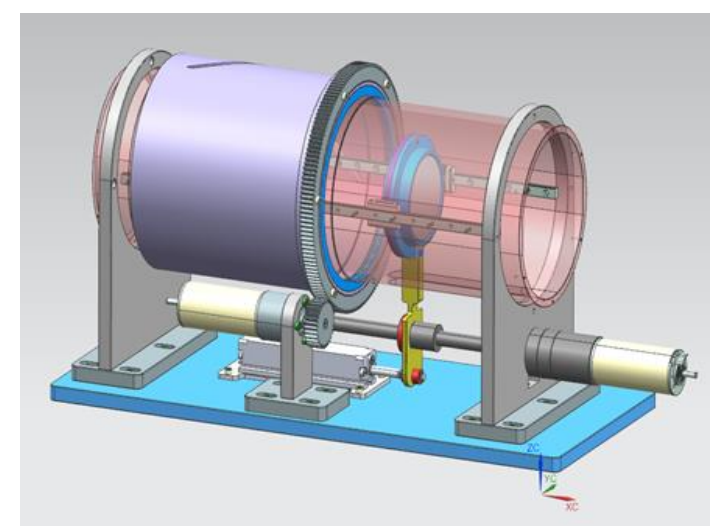

Şekil 24. Odak mercek grubu hareketi için seçilen motorun konumlandırılması 


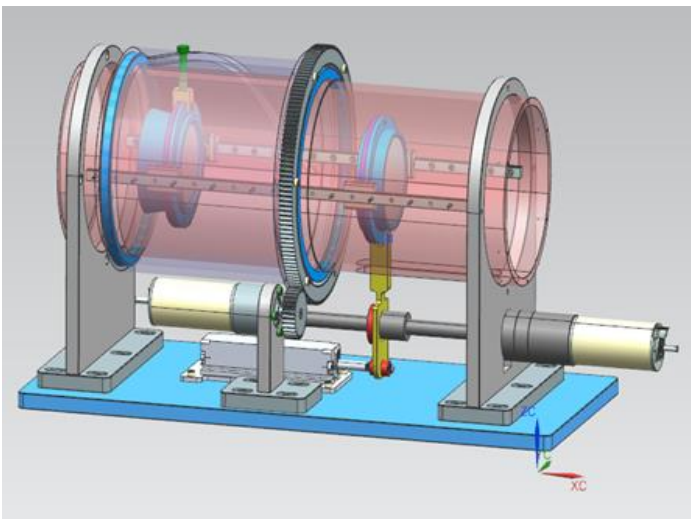

Şekil 25. Zoom mercek grubunun konumlandırılması

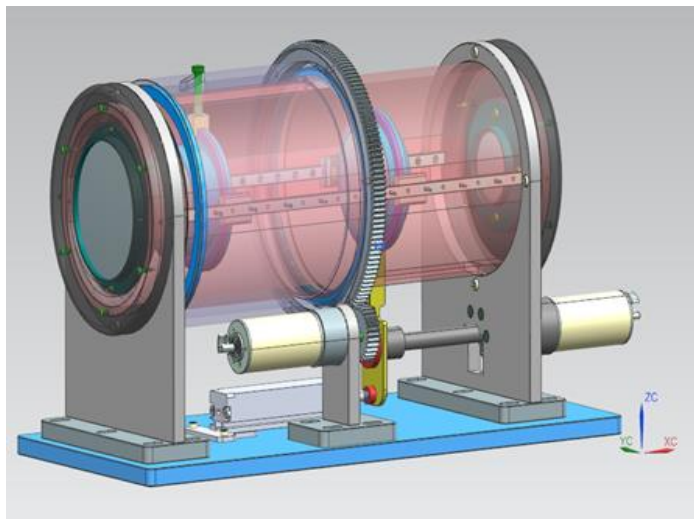

Şekil 26. Hareketsiz mercek gruplarının konumlandırılması

\section{Sistemin Bütünlenmesi}

Tasarımı yapılan parçaların üretimi için malzeme seçimi yapılmıştır. Sistemi taşıyacak olan parçalar için mukavemet açısından alüminyumdan üretimi yapılırken, diğer parçalar için sanayi plastikleri tercih edilmiştir. Sanayi plastikleri tercih edilerek sistemin daha düşük atalete sahip olması hedeflenmiştir. Dişlilerin üretimi için fiziksel, kimyasal, mekanik ve birçok özelliği itibariyle mükemmel bir malzeme olan poliasetal (delrin) tercih edilirken, mercek grupları ve kam gibi parçalar içinde, tok ve rijit bir malzeme olmasının yanında yüksek darbe dayanımının olması, kolay işlenebilmesi ve hafif bir malzeme olmasından dolayı akrilonitril bütadiyen stiren (ABS) tercih edilmiştir.

Şekil 27'de ABS malzemeden üretilen odak mercek grubunun, alüminyumdan üretilen ara parçalar ile doğrusal yatağa bütünlenmesi gösterilmektedir. Şekil $28^{\prime}$ 'de gösterildiği gibi sistemin bütünlemesine, üretilen hareketli mercek gruplarını doğrusal yatağa montajı ile başlanmıştır,

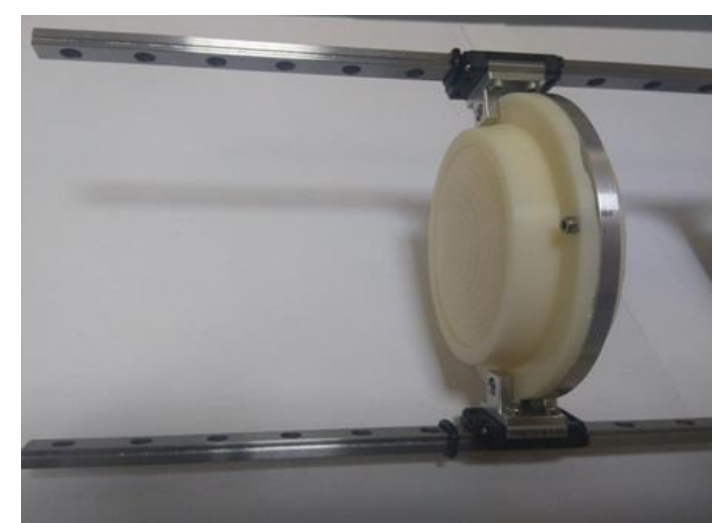

Şekil 27. Odak mercek grubun bütünlenmesi

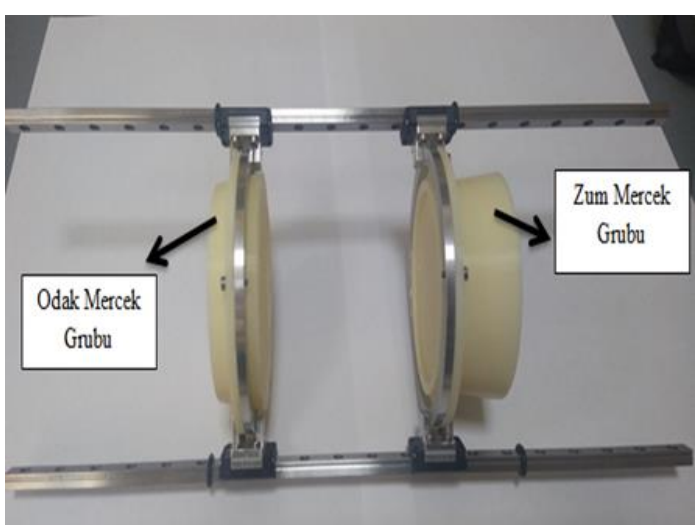

Şekil 28. Hareketli mercek gruplarının bütünlenmesi

Şekil 29'da verildiği gibi hareketli mercek gruplarının bütünlendiği doğrusal yatak, sabit kısma bütünlenmiştir. Sabit kısmın üstünde bulunan silindirik kam, ince kesit rulmanlar ve delrin malzemeden üretilen dişli parçası bütünlenmiştir ve Şekil 30'da bütünlenmiş hali gösterilmektedir. 


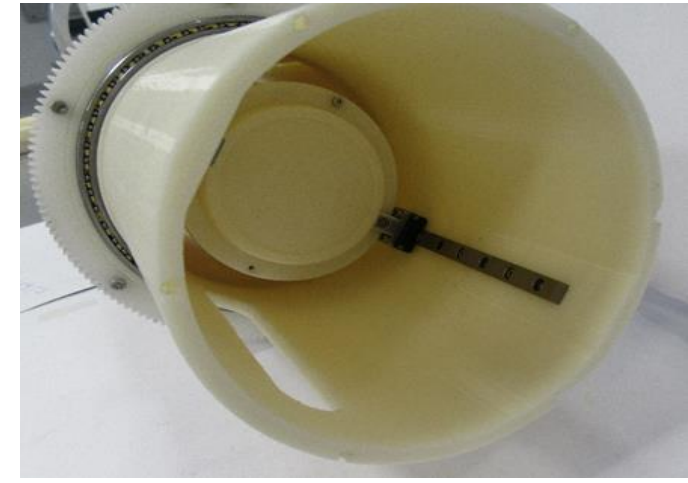

Şekil 29. Doğrusal yatağın bütünlenmesi

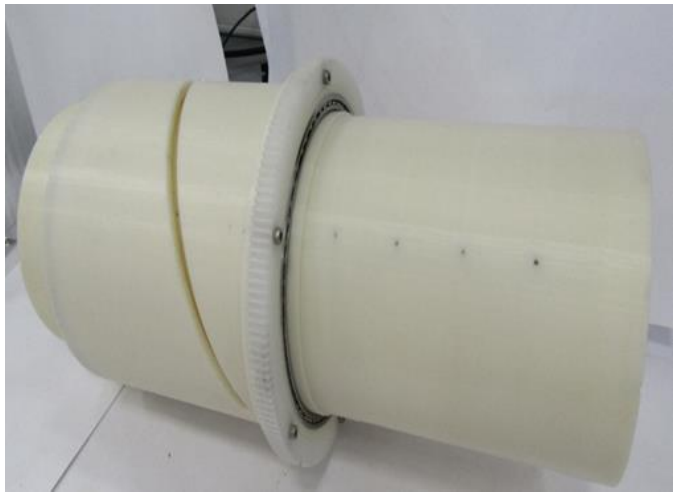

Şekil 30. Silindirik kamın bütünlenmesi

Değişken odaklı görüntüleme sisteminin yerleştirileceği alt tabla ve parçalar tasarıma uygun olarak bütünlenmiştir. Sistemin bütünlenmiş halinin farklı açılardan Şekil 31- 32‘de gösterilmiştir.

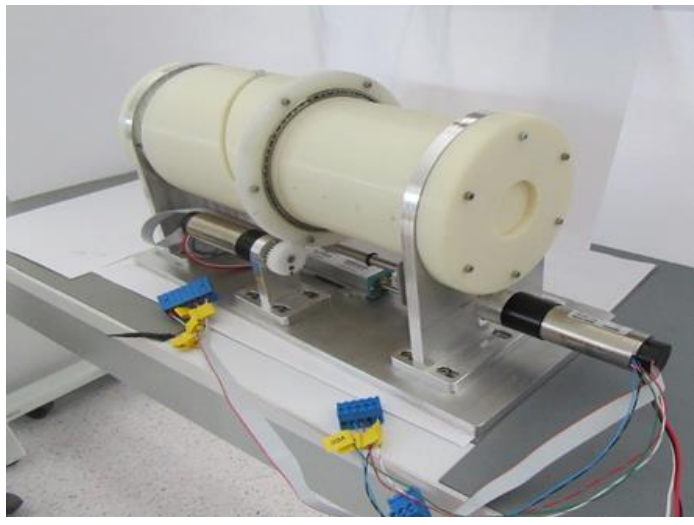

Şekil 31. Sistemin bütünlenmesi

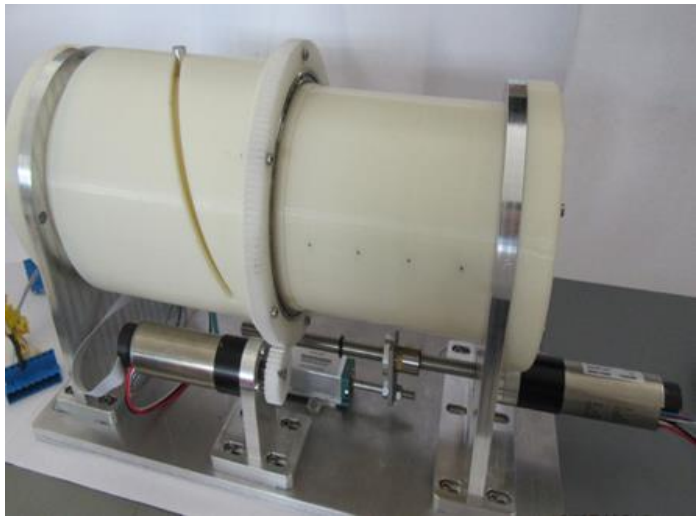

Şekil 32. Sistemin bütünlenmesi

\section{Sistemin Matlab Destekli Manuel Olarak Çalıştırılması}

Sistem tasarımının kontrolü Matlab $^{\circledR}$ üzerinden simulink real time test ${ }^{\circledR}$ ile yapılmıştır [19]. Simulink gerçek zaman testin temel yapısı Şekil 33 'te gösterilmektedir.

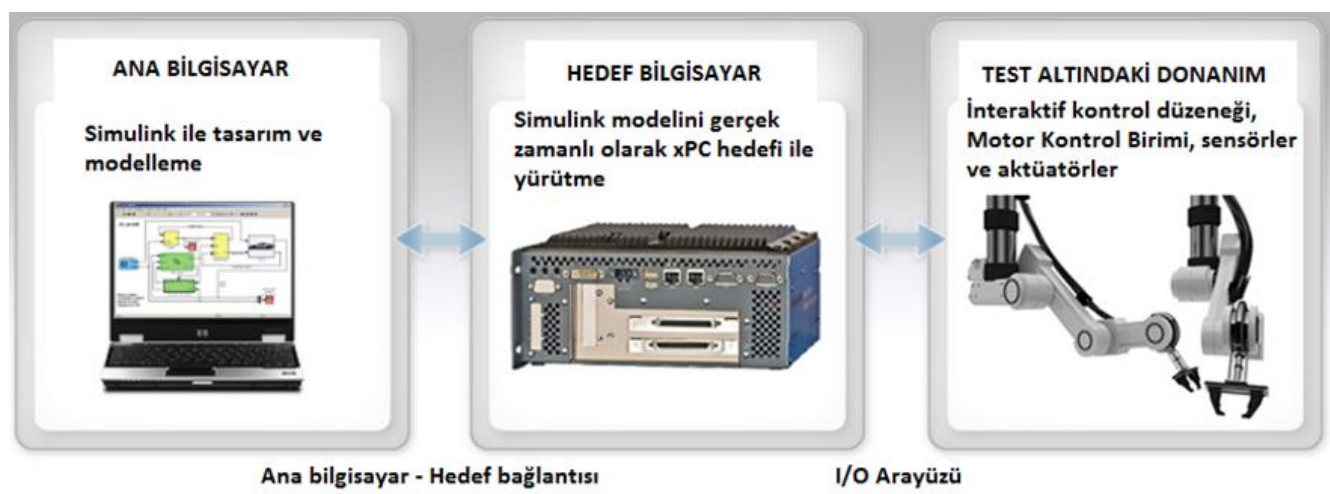

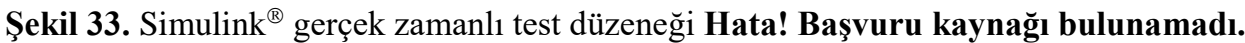


$\mathrm{Bu}$ yöntem temel anlamda simulink üzerinden hazırlanan program ile gerçek sistemi kontrol etmek için kullanılmaktadır. Simulink' de hazırlanan komutlar ile sistem çalıştırılıp; yine aynı şekilde sistem üzerinde bulunan algılayıcılardan gelen verilen okunarak veri toplanarak gerekli çalışmalar yapılmaktadır. Bu makale kapsamında, tasarımı kontrol için hazırlanan gerçek zamanlı test sisteminde NI 6289 veri okuma kartı kullanılarak enkoder değerleri elde edilmiştir.

Kam mekanizması tasarlanırken Şekil 34'te gösterildiği gibi tasarlanmıştır. Kamın hareket ettiği açı aralığında doğrusal hareket eğrisi tanımlanarak tasarım yapılmıştır. Bu tasarımın amacı Tablo 1'de verilen zoom mercek grubunun konumlarını kapsayan bir hareket aralığında kam mekanizması oluşturmaktır. Burada 122 mm olarak verilen ölçü, mercek grubunun doğrusal olarak alması gereken yol miktarını kapsamaktadır. $230 \mathrm{~mm}$ değeri kamın kaç derede dönüş yaparak bu hareketi sağlayacağını gösterir, bu değer sistemin genel yapısına göre belirlenmiştir. Tasarlanan kamın dış çapı 140 mm'dir. Bu değer, kam içerisine yerleştirilecek mercek gruplarını kapsayacak şekilde belirlenir. 230 mm ile kamın dönüş açısı arasındaki ilişki denklem (1) ve (2) 'de gösterilmiştir.

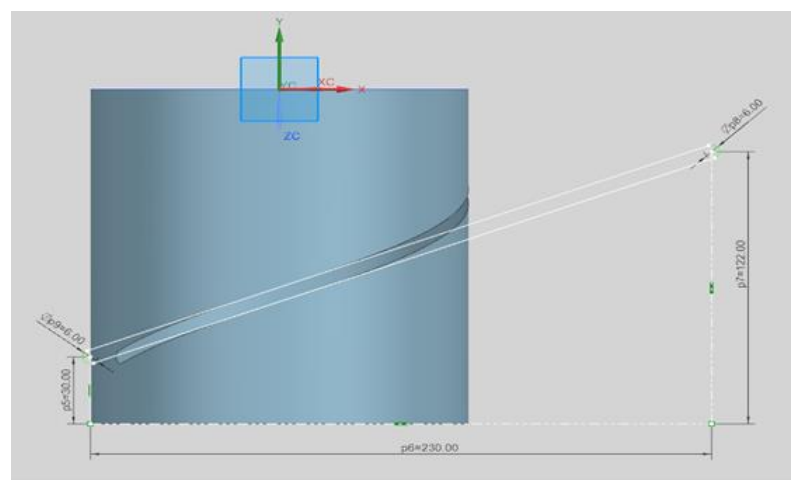

Şekil 34. Kam mekanizmasının tasarımı

tur $=\frac{230}{2 \times \pi \times r}=\frac{230}{2 \times \pi \times 70}=0.52$

kam toplam dönüş aç1s1 $=\operatorname{tur} \times 360=0.52 \times 360=187.2^{\circ}$

Zoom mekanizmasındaki motora akım verilmeden, sadece enkoder okuyarak kam hareketi gerçekleştirilmiştir. Bu işlem yapılırken Şekil 35'te gösterilen model kullanılmıştır, motorda bulunan dişli kutusu aktarma oranına ve değişken odaklı sistem tasarımında bulunan dişli aktarma oranına dikkat edilmiştir.

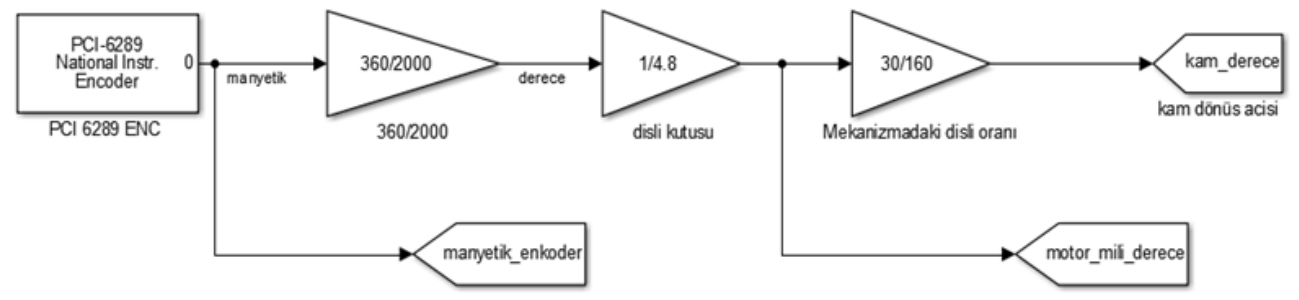

Şekil 35. Kam mekanizmasının doğrulanması

Şekil 35'de gösterilen model kullanılarak, kam mekanizması manuel olarak çalıştırılıp deneysel olarak Şekil 36-38'de gösterilen sonuçlar elde edilmiştir, ayrıca kam mekanizmasının tasarlanan hareketi gerçekleştirdiğinde yarım tur döndüğü deneysel olarak gözlemlenmiştir. Şekil 35'de gösterilen modelde "manyetik_enkoder" adıyla tanımlanan kam motoru enkoderinin saydığı değer Şekil 36'da gösterilmektedir. Şekil 35'de gösterilen modelde "motor_mili_derece" ve "kam_derece" adıyla tanımlanan motor milinin ve kamın dönüş açısı derece cinsinden 
Şekil 37’de gösterilmiştir. Gözlemlenen görüş açıları ile ölçülen görüş açılarının kıyaslanması için, ölçülen görüş açıları 360'a bölünerek tur cinsinden karşllı̆̆ bulunmuştur ve Şekil 38'de gösterilmiştir.

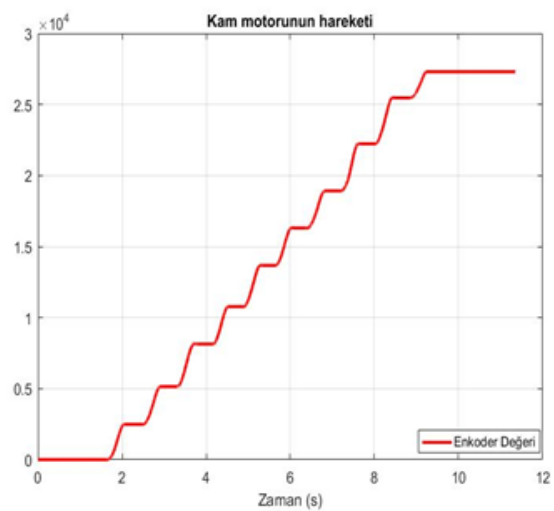

Şekil 36. Enkoderin saydı̆̆g değer

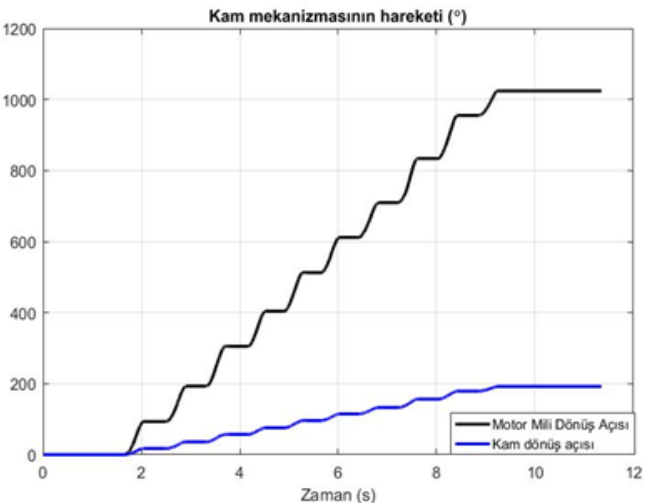

Şekil 37. Dönüş açıları

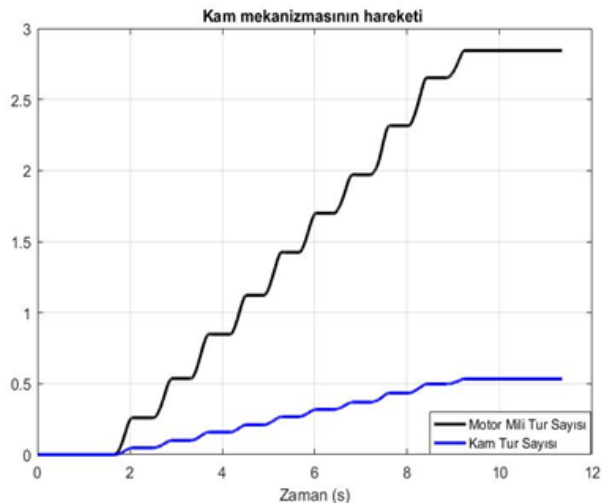

Şekil 38. Tur sayısı

Odak mekanizmasında kullanılan motorun özelliklerinde tur başına ilerleme miktarı 2 mm olarak belirtilmiştir. Bu hareketi ölçmek için odak mekanizmasına bağlı olan doğrusal potansiyometre kullanılmıştır. Şekil 39'da gösterilen ve motor dişli kutusu oranlarını içeren model çalıştırılarak, deneysel olarak manuel bir tur motor hareket ettirilip doğrusal potansiyometredeki konum değişimine bakılmıştır. Şekil 39'da gösterilen modelde “manyetik_enkoder" adıyla tanımlanan odak motoru enkoderinin saydığ 1 değer Şekil 40’da gösterilmektedir. Şekil 39'da gösterilen modelde "motor_mili_derece" adıyla tanımlanan odak motorunun dönüş açısının derece cinsinden karşılığ tur cinsine çevirilerek Şekil 41'de gösterilmiştir. Şekil 39'da gösterilen modelde "pot_out_1" adıyla tanımlanan doğrusal potansiyometreden okunan konum değeri Şekil 42'de gösterilmiştir. Şekil 40-42'daki grafiklerden de görüldüğü üzere motorun hareketine karşılık 2 mm'lik konum değişimi sağlanmıştır.
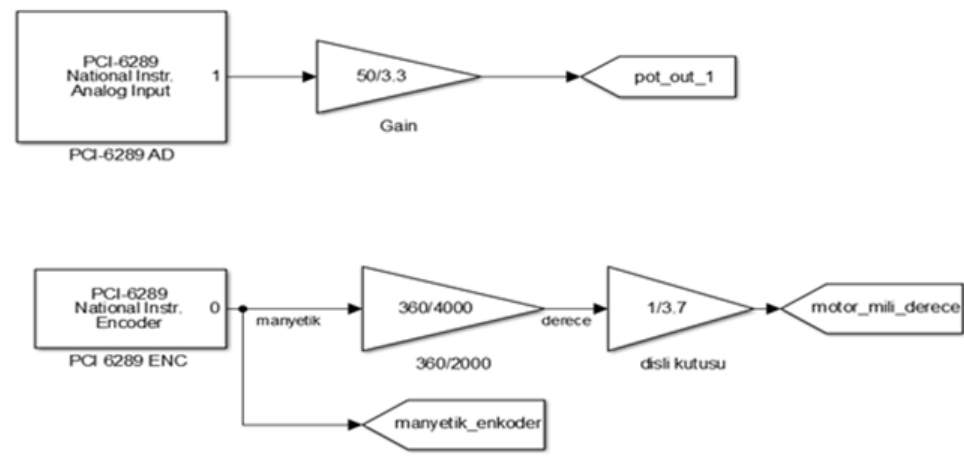
Şekil 39. Odak mekanizmasının doğrulanması

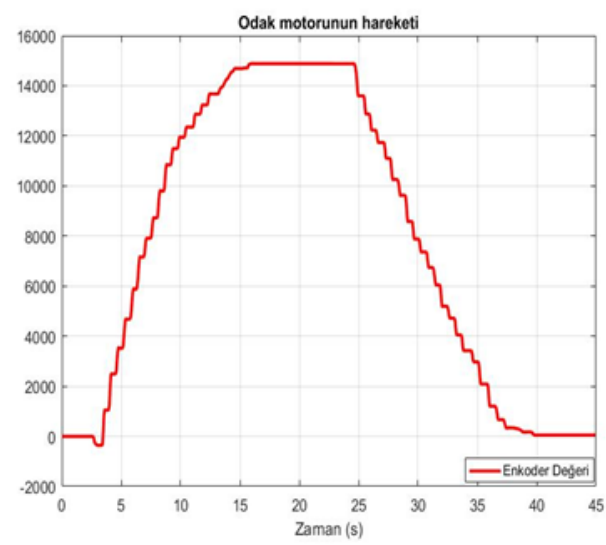

Şekil 40. Odak motoru enkoder değeri

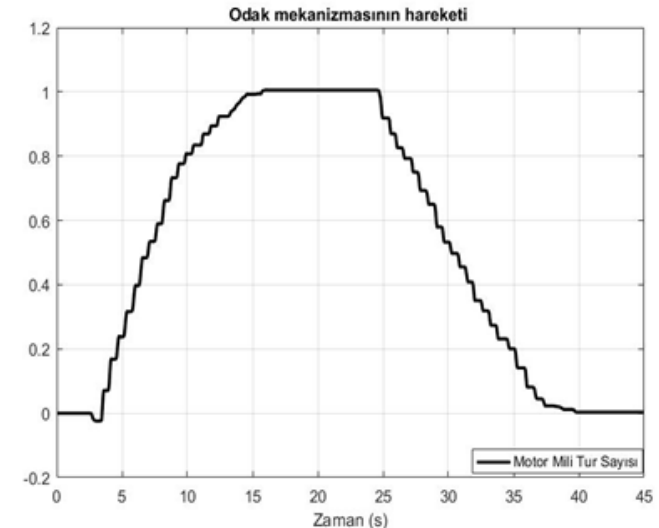

Şekil 41. Odak motor mili tur sayısı

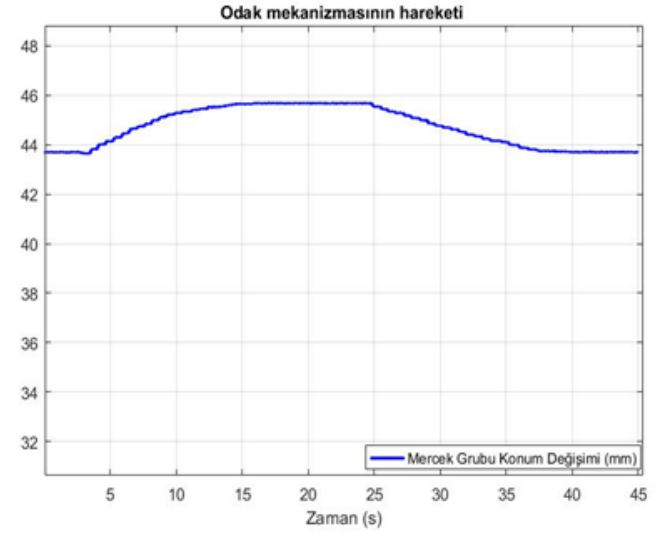

Şekil 42. Doğrusal potansiyometre ile okunan konum değişimi

\section{Tartışma ve Sonuç}

Bu makale kapsamında optik görüntüleme sistemleri için değişken odaklı sistem tasarımı, üretimi ve Matlab destekli manuel tasarım doğrulaması yapılmıştır. Bu bağlamda konuyla ilgili yapılmış çalışmalar incelenerek sistemin temel mekanizma yapısına karar verilmiştir. Yapılan araştırmalar sonucunda zoom ve odak mekanizması için iki ayrı motor ve mekanizma kullanıldığı gözlemlenerek tasarım kararları verilmiştir. Mekanizma seçiminde ise zoom sistemleri için silindirik kam mekanizmalarının kaçınılmaz olduğu gözlemlenmiş ve vida mekanizmalarının da tercih edildiği uygulamalar olduğu görülmüştür. Bunun sonucunda zoom mercek grubu için silindirik kam mekanizması, odak mercek grubu için vida mekanizması tercih edilmiştir. Sistem seviyesinde tasarım yapıldığı için sistemi oluşturan motor, rulman ve doğrusal yatak gibi parçaların sistemde konumlandırılmasına önem verilmiştir. Son olarak Sistem tasarımı tamamlandıktan sonra tasarım doğrulaması için Matlab $^{\circledR}$ üzerinden simulink real time test ${ }^{\circledR}$ ile yapılmış ve hedeflenen sonuçlar alınmış̧ır. Bunlarla birlikte tasarımı yapılan sistem, endüstride bulunan sistemlerden üstün özelliklere sahip değildir ancak bu sistemlerin temel yapısını anlatmaktadır ve geliştirmeye açıktır. 


\section{Kaynaklar}

[1] Genç E, POLAT M. Optik Görüntüleme Sistemleri için Değişken Odaklı Sistem Tasarımı. TOK2018 Otomatik Kontrol Ulusal Toplantıs1. 12-14 Eylül 2018. pp. 391-394.

[2] Paul R, Yoder Jr. Opto-Mechanical Systems Design. Üçüncü Baskı. Taylor \& Francis Group. 2006.

[3] Li Y, Hu C, Chen J, Haihuna F, Wang Y. and Lu F. Optical and Mechanical Design of 10X Zoom Lens for Low-Vision Devices. Proc. of SPIE,2012, Vol. 8419 84190R.

[4] Sanson MC, Cornell J. MWIR Continuous Zoom with Large Zoom Range. Proc. of SPIE,2010, Vol. 7660 $76601 \mathrm{X}-1$

[5] Sanson MC, Cornell J, Roy B, Herbert S, Woodard K, Sawywer K. Development of MWIR Contınuous Zoom with Large Zoom Range. Proc. of SPIE,2011. Vol.8012 80122F.

[6] Yan-qin S, Jing-xu Z, Tian-yu L, Fei Y, Fu-guo W. Mechanism Design of Continuous infrared Lens. Proc. of SPIE,2013. Vol. 8907890735.

[7] Gao Y, Yang Z, Zhao W, Jiang B, Li D, Li M. Optimum Design of Cam Curve of Zoom Systems Based on ZEMAX. Optik 124.2013. pp. 6358-6362.

[8] Mann A. Developments and trends in IR Zoom Lenses from 2000 to 2010. ,Proc. of SPIE,2012. Vol. 8488 848805.

[9] Sever AÇ. Preparation of a Computer Aided Design Package for Opto-mechanical Design of Forward Looking Infrared Systems. Orta Doğu Teknik Üniversitesi. 2001.

[10] http://www.ophiropt.com /Erişim: 01-May-2018

[11] Aslan SH, Anıl D. Sürekli Odaklı 3-5 $\mu \mathrm{m}$ Bandında FLIR Optik Tasarım Çalışması. SAVTEK 2014. Savunma Teknolojileri Kongresi. Orta Doğu Teknik Üniversitesi Ankara.

[12] DiBiase D, Bardis J, Billing R. A Zoom Lens for the MSL Mast Cameras: Mechanical Design and Development. Proceedings of the 41st Aerospace Mechanisms Symposium. Jet Propulsion Laboratory. May 16-18, 2012.

[13] Koyunbakan M. Bilgisayar Destekli Kam Tasarımı ve Örnek Bir Kam Mekanizmasının İmalatı. Yüksek Lisans Tezi, Dumlupınar Üniversitesi Fen Bilimleri Enstitüsü, Kütahya , Türkiye, 2006.

[14] http://ocw.metu.edu.tr/ Erişim: 05-Haz-2018

[15] Robert L, Norton PE. Cam Design and Manufacturing Handbook. Industrial press,2009.

[16] Söylemez E. Mekanizma Tekniği. 4.Baskı, Birsen Yayınevi, 2017.

[17] Akkurt M. Makine Elemanları. Üçüncü Baskı, Birsen Yayınevi.

[18] Paul E. Sandin. Robot Mechanisms and Mechanical Devices. McGraw-Hill Companies,2003.

[19] https://www.mathworks.com/products/simulink-real-time.html / Erişim: 05-Tem-2018 